\title{
Compressive Behaviour of Concrete by Using Bagasse Ash From Sugar Mill
}

\author{
Safayat Mahmud, Md. Imamul Islam, Rubieyat Bin Ali ${ }^{*}$, \\ Md. Mofizul Islam, Md. Mahadi Hasan \\ Department of Civil Engineering, Rajshahi University of Engineering \& Technology, Rajshahi, Bangladesh.
}

Received 21 March 2018; accepted 10 December 2018; available online 24 December 2018

DOI: https://10.30880/jst.2018.10.03.008

\begin{abstract}
The materials which are useless and unwanted is called waste product and this waste product is a burden and harmful to the environment. Sugarcane bagasse ash (SCBA) is one kind of waste which can be termed as the residue left over from burning sugar cane bagasse. The utilization of this waste may be very economical and can also solve the environmental problem. Silica and alumina are the main element of SCBA which is used as a pozzolanic material. This recycling procedure of SCBA reduces environmental pollution and this is also considered the cost-effective material. In this paper, SCBA replaces the cement as a weight of $5 \%, 10 \%$ and $15 \%$ which is considered. After completing the compressive strength test, the result shows that the compressive strength increases when $5 \%$ cement is replaced by sugarcane bagasse ash and this is the correct replacement of cement.
\end{abstract}

Keywords: Sugarcane bagasse ash (SCBA); pozzolanic material; compressive strength.

\section{Introduction}

Bangladesh is a developing country. As a developing country focus should give on ways of utilizing the waste products. This utilization should reduce the environmental pollution. There are many waste product sources in Bangladesh. Among those sources, sugar mill is one of them. There are several sugar mills in Bangladesh which produce eight lakhs ton sugar can bagasse approximately ash per year [1]. The main challenge is to dispose and manage this big amount of wastes. These rubbishes can be applied to the soil to create the agricultural environment for the production of different crops. The production rate and quantity of this rubbish are huge and costly to transport these anywhere. So, composting may be the solution to that issue. To compost these wastes, it can be used in many fertilizers companies in order to apply it as a fertilizer. In many countries such as Brazil, India, Canada etc. having big amounts of sugar mill factory. Sathiya et al. (2010) inspected on the physical properties of bags, ash which is found from the sugar mill boiler. They found that this bagasse ash contains big amounts of aluminum and $\mathrm{CaO} 2$ which having good pozzolanic and binding property [2]. And these pozzolanic materials are very important materials to increase durability and strength of concrete. The Specific code should be predicated on the use of SCBA in concrete for the specific replacement of cement. So, this is the potential research gap in this study. The main goals of this study are to compute the compressive strength, slump value or workability of concrete by using the sugarcane bagasse ash in lieu of a certain amount of cement.

\section{Literature Review of Previous Study}

Otuze et al. Commented that if SCBA will mix with OPC (Ordinary Portland cement) then it can give good strength and better pozzolanic property. He replaced the $10 \%$ amount of cement by SCBA and observed that the workability and compressive strength was increased [3].

Kawade et al. Inspected on the effect of compressive strength of concrete, which is mixed with $0 \%, 10 \%, 15 \%, 20 \%, 25 \%$ and $30 \%$ SCBA in the replacement of cement. All tests were done according to American standards. He also found that the workability of fresh concrete can be increased by the partial replacement of cement by SCBA [4].

Modani et. al. (2013) investigated the replacement of $10 \%$ fine aggregate by bagasse ash to compute the tensile strength of concrete. He found that this type of replacement increased the concrete tensile strength. He also detected that if 
the amount of replacement of fine aggregate will more than $10 \%$ than the tensile strength will be decreased in concrete. And all tests were performed according to IS 5816:1999 [Indian standards] [5].

DR. M. Vijaya S. R. et al. (2015) showed that if the $10 \%$ amount of blended SCBA is mixed with concrete in the replacement of cement, then the increasing rate of compressive strength will high. He suggested that to keep the amount of blended SCBA up to $10 \%$ in concrete [6].

Irfan A. N. et al. (2017) showed that the SCBA can modify the concrete performance and increase the durability and strength of paver blocks because of the existence of the high amount of silica in sugarcane ash. And these pavements are unaffected by the seepage of oil from vehicles and are ideal for bus stops and parking areas [7].

\section{Experimental Materials}

Sugarcane bagasse ash (SCBA) is considered as the partial replacing material of cement in concrete mix design and this is the present experimental investigation. On the replacement of cement with the different weight percentage of SCBA, the workability and compressive strength are studied at different curing age of concrete in different environments like normal water and $\mathrm{HCl}$ diluted solution. The details of experimental investigations are as follows.

\subsection{Cement}

OPC (Ordinary Portland Cement) of 53 grades is used for this work and this type of cement is kept in the favorable container which is provided the friendly temperature for cement and acted as a guard from bad temperature and humidity. The physical properties of cement are tested according to IS: 12269-1987 [8]. Table 1 shows the physical properties of cement.

\subsection{Sugarcane Bagasse Ash}

Cellulose (50\%) and lignin hemicellulose $(25 \%)$ are the main components of the SCBA. Sugarcane generates $26 \%$ bagasse per ton. Here $26 \%$ bagasse contains $50 \%$ moisture content and $0.62 \%$ residual ash. After combustion, the residue presents a chemical composition which is dominated by $\mathrm{SiO} 2$ [9].
And the ash is one kind of fertilizer which is used during sugarcane harvesting season. In this SCBA is collected during the cleaning operation of a boiler in the sugar factory, located in the town of Natore, the division of Rajshahi in Bangladesh. The physical and chemical properties of SCBA are tested in the Solid mechanics and chemistry laboratory of Rajshahi University of Engineering and Technology. Fig. 1 shows the physical, pictorial view of SCBA. And Table 2 and Table 3 are represented the physical and chemical properties of SCBA.

Table 1 Physical properties of cement

\begin{tabular}{|c|c|c|}
\hline $\begin{array}{c}\text { Serial } \\
\text { No. }\end{array}$ & Property & Value \\
\hline 1. & Normal Consistency & $33 \mathrm{~mm}$ \\
\hline 2. & Fineness of cement & $7 \%$ \\
\hline 3. & $\begin{array}{c}\text { Setting times } \\
\text { Initial (Minutes) } \\
\text { Final(Minutes) }\end{array}$ & 80 \\
& \multicolumn{2}{|c|}{240} \\
\hline
\end{tabular}

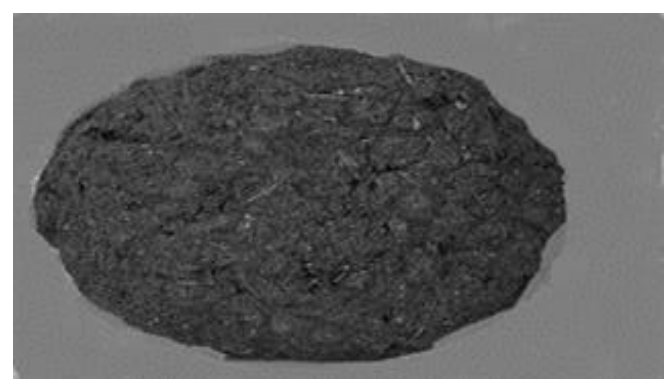

Fig. 1 Sugarcane bagasse ash

Table 2 Physical properties of SCBA

\begin{tabular}{|c|c|c|}
\hline $\begin{array}{c}\text { Serial } \\
\text { No. }\end{array}$ & Property & Value \\
\hline 1 & Density & $575 \mathrm{~kg} / \mathrm{m}^{3}$ \\
\hline 2 & Specific gravity & 2.2 \\
\hline 3 & Mean particle size & $0.1-0.2 \mu \mathrm{m}$ \\
\hline 4 & $\begin{array}{c}\text { Minimum specific } \\
\text { surface area }\end{array}$ & $2500 \mathrm{~m}^{2} / \mathrm{kg}$ \\
\hline 5 & Particle shape & Spherical \\
\hline
\end{tabular}


Table 3 Chemical composition of SCBA

\begin{tabular}{|c|c|c|c|}
\hline $\begin{array}{c}\text { Serial } \\
\text { No. }\end{array}$ & Component & Symbol & $\begin{array}{c}\text { Percentage } \\
(\%)\end{array}$ \\
\hline 1 & Silica & $\mathrm{SiO}_{2}$ & 63 \\
\hline 2 & Alumina & $\mathrm{Al}_{2} \mathrm{O}_{3}$ & 31.5 \\
\hline 3 & $\begin{array}{c}\text { Ferric } \\
\text { Oxide }\end{array}$ & $\mathrm{Fe}_{2} \mathrm{O}_{3}$ & 1.79 \\
\hline 4 & $\begin{array}{c}\text { Manganese } \\
\text { Oxide }\end{array}$ & $\mathrm{MnO}$ & 0.004 \\
\hline 5 & $\begin{array}{c}\text { Calcium } \\
\text { Oxide }\end{array}$ & $\mathrm{CaO}$ & 0.48 \\
\hline 6 & $\begin{array}{c}\text { Magnesium } \\
\text { Oxide }\end{array}$ & $\mathrm{MgO}$ & 0.39 \\
\hline 7 & $\begin{array}{c}\text { Loss of } \\
\text { Ignition }\end{array}$ & $\mathrm{LOI}$ & 0.71 \\
\hline
\end{tabular}

\subsection{Fine Aggregate}

Sylhet sand is taken for this work. Sylhet sand is collected from the Sylhet division of Bangladesh. The sand is free of organic, clay and silt impurities. The properties of Sylhet sand are given in Table 4.

Table 4 Properties of fine aggregate

\begin{tabular}{|c|c|c|}
\hline $\begin{array}{c}\text { Serial } \\
\text { No. }\end{array}$ & Property & Value \\
\hline 1 & Specific gravity & 2.60 \\
\hline 2 & Fineness modulus & 2.74 \\
\hline
\end{tabular}

\subsection{Coarse Aggregate}

Two types of coarse aggregate are chosen for this work. One is $3 / 4$ downgrade (Black) $(70 \%$ of the total weight of coarse aggregate) and $1 / 2$ inch stone chips (Black) (30\%). Specific gravity and fineness modulus are measured for both of them. So, those properties are shown in Table 5.
Table 5 Properties of coarse aggregate

\begin{tabular}{|c|c|c|}
\hline $\begin{array}{c}\text { Serial } \\
\text { no }\end{array}$ & Property & Value \\
\hline 1 & $\begin{array}{c}\text { Specific gravity (3/4 } \\
\text { downgrade) }\end{array}$ & 2.70 \\
\cline { 2 - 3 } & $\begin{array}{c}\text { Specific gravity (1/2 inch } \\
\text { stone chips) }\end{array}$ & 2.60 \\
\hline 2 & $\begin{array}{c}\text { Fineness modulus (3/4 } \\
\text { downgrade) }\end{array}$ & 6.91 \\
\cline { 2 - 3 } & $\begin{array}{c}\text { Fineness modulus (1/2 } \\
\text { inch stone chips) }\end{array}$ & 6.00 \\
\hline
\end{tabular}

\subsection{Water}

The fresh water which is free from any type of wastes is used in mixing operation. And the required amount of water is kept in the graduated jar which is measured by digital weight machine. The $\mathrm{PH}$ value must greater than 7 in that mixing operation.

\subsection{Mix proportions}

According to IS-10262-2009, Mix designs of M20 concrete are conducted [10]. In cement, $0 \%, 5 \%$, $10 \%$ and $15 \%$ replacement operation are done by Bagasse ash and these are used in concrete. The 6-inch diameter and 12-inch height cylinder are chosen for conducting our compressive strength and workability. So, Table 6 shows the mix proportions for M20 concrete.

Table 6 Mix proportions for M20 concrete.

\begin{tabular}{|c|c|c|c|c|c|}
\hline \multirow{2}{*}{ Parameters } & \multicolumn{6}{|c|}{ Percentage Replacement of Bagasse Ash } \\
\cline { 2 - 6 } & $\begin{array}{c}\text { CONTRO } \\
\text { L MIX }\end{array}$ & $\begin{array}{c}\text { MIX 1 1 } \\
(0 \%)\end{array}$ & $\begin{array}{c}\text { MIX 2 } 2 \\
(5 \%)\end{array}$ & $\begin{array}{c}\text { MIX 3 } \\
(10 \%)\end{array}$ & $\begin{array}{c}\text { MIX 3 } \\
(15 \%)\end{array}$ \\
\hline W/C Ratio & 0.51 & 0.51 & 0.54 & 0.57 & 0.60 \\
\hline Water (kg) & 1 & 1 & 1 & 1 & 1 \\
\hline Cement (kg) & 1.93 & 1.93 & 1.83 & 1.73 & 1.65 \\
\hline $\begin{array}{c}\text { Fine } \\
\text { aggregates } \\
\text { (kg) }\end{array}$ & 4.34 & 4.34 & 4.34 & 4.34 & 4.34 \\
\hline $\begin{array}{c}\text { Coarse } \\
\text { aggregates } \\
\text { (kg) }\end{array}$ & 5.52 & 5.52 & 5.52 & 5.52 & 5.52 \\
\hline $\begin{array}{c}\text { Bagasse } \\
\text { Ash (kg) }\end{array}$ & 0 & 0 & 0.096 & 0.193 & 0.28 \\
\hline
\end{tabular}




\section{Experimental Result}

\subsection{Workability}

Workability of a fresh concrete is determined by the slump value test. Concrete strength depends on the good workability of fresh concrete. And good workability also depends on the high slump value. The main components of workability are consistency and stability. Here, stability also depends on two indexes. One is water retaining capacity which is the opposite form of bleeding and another is coarse aggregate retaining capacity which is the opposite form of segregation. Table 7 shows the slump test value of SCBA mixing concrete.

Table 7 Slump test value of SCBA mixing concrete

\begin{tabular}{|c|c|c|}
\hline $\begin{array}{c}\text { Sample } \\
\text { designation }\end{array}$ & $\begin{array}{c}\text { \% of } \\
\text { SCBA }\end{array}$ & $\begin{array}{c}\text { Slump } \\
\text { Value } \\
\text { (mm) }\end{array}$ \\
\hline $\mathrm{A}$ & 0 & 15 \\
\hline $\mathrm{B}$ & 5 & 19 \\
\hline $\mathrm{C}$ & 10 & 37 \\
\hline $\mathrm{D}$ & 15 & 49 \\
\hline
\end{tabular}

From the analysis of this table, it is clearly shown that slump value increases with the increase of $\%$ of SCBA with the replacement of cement in concrete. So, it is cleared that concrete mixed with SCBA increases the workability of concrete. Fig. 2 shows the graphical view of slump values.

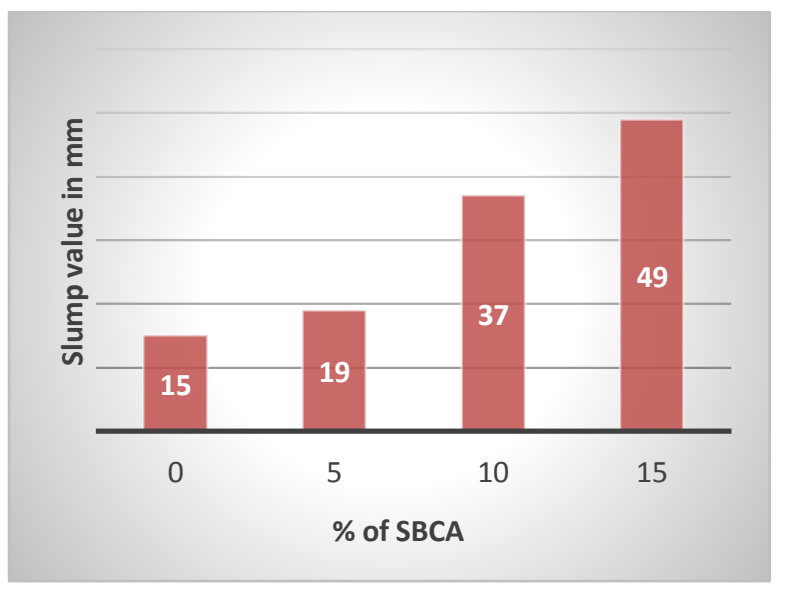

Fig. 2 Slump value vs. $\%$ of SCBA

\subsection{Compressive Strength of Concrete}

The compressive strength tests are conducted at 7 and 28 days of 4 types of the specimen. Table 8 and 9 show the compressive strength test result of concrete specimens with $0 \%, 5 \%, 10 \%$ and $15 \%$ SCBA with the replacement of cement.

Table 8 Strength Results of SCBA concrete in 7 Days

\begin{tabular}{|c|c|c|}
\hline $\begin{array}{c}\text { Sample } \\
\text { designation }\end{array}$ & $\begin{array}{c}\text { \% of } \\
\text { SCBA }\end{array}$ & $\begin{array}{c}\text { Compressive } \\
\text { strength } \\
\text { (M pa) }\end{array}$ \\
\hline $\mathrm{A}$ & 0 & 16.85 \\
\hline $\mathrm{B}$ & 5 & 20.05 \\
\hline $\mathrm{C}$ & 10 & 15.32 \\
\hline $\mathrm{D}$ & 15 & 13.93 \\
\hline
\end{tabular}

From the above table, it is observed that the specimen of $0 \%$ SCBA with the replacement of cement, the compressive strength is $16.85 \mathrm{MPa}$ but at 5\% SCBA this strength is increased in $20.05 \mathrm{MPa}$. At $10 \%$ and $15 \%$, it is shown that the compressive strength is decreased by $15.32 \mathrm{MPa}$ and $13.93 \mathrm{MPa}$. So, up to 0 to $5 \%$, SCBA with the replacement of cement in concrete gives better strength and this proportion is suggested to use practically. And Fig. 3 presents the pictorial graph of this test result.

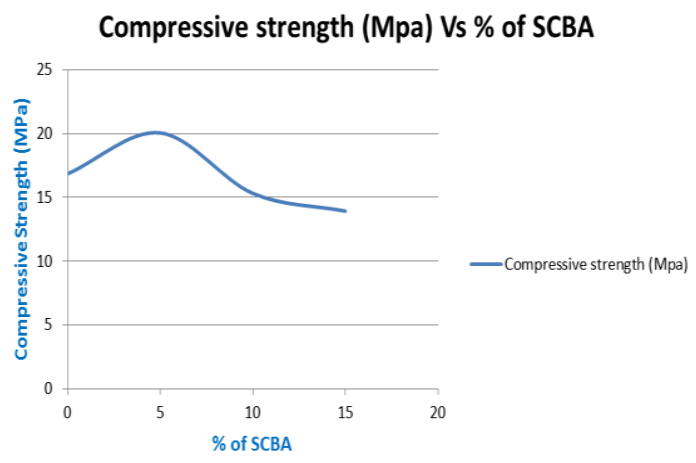

Fig. 3 Compressive strength for 7 days.

From the analysis of this figure, it is seen that the compressive strength of SCBA concrete obtains its maximum strength as a result of mixing $5 \%$ of sugarcane bagasse ash. 
Table 9 Compressive strength of SCBA concrete for 28 days

\begin{tabular}{|c|c|c|}
\hline $\begin{array}{c}\text { Sample } \\
\text { designation }\end{array}$ & $\begin{array}{c}\text { \% of } \\
\text { SCBA }\end{array}$ & $\begin{array}{c}\text { Compressive } \\
\text { Strength } \\
\text { (MPa) }\end{array}$ \\
\hline $\mathrm{A}$ & 0 & 24 \\
\hline $\mathrm{B}$ & 5 & 28.6 \\
\hline $\mathrm{C}$ & 10 & 22.63 \\
\hline $\mathrm{D}$ & 15 & 20.54 \\
\hline
\end{tabular}

From the above table, it is observed that at 28 days the specimen of $0 \%$ SCBA with the replacement of cement, the compressive strength is $24 \mathrm{MPa}$ but at 5\% SCBA this strength is increased in $28.6 \mathrm{MPa}$. At $10 \%$ and $15 \%$, it is shown that the compressive strength is decreased by $22.63 \mathrm{MPa}$ and $20.54 \mathrm{MPa}$. So, up to 0 to $5 \%$, SCBA with the replacement of cement in concrete gives better strength at 28 days. And Fig. 4 presents the pictorial graph of this test result.

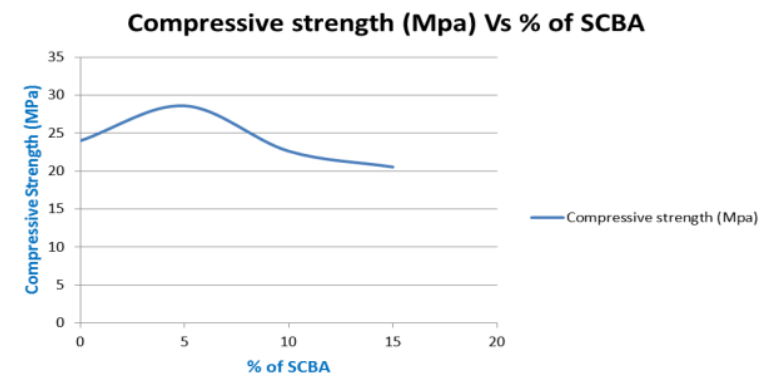

Fig. 4 Compressive strength for 28 days.

The main reason for increasing strength of 5\% SCBA in concrete is the presence of $\mathrm{Si}$ in SCBA. This $\mathrm{Si}$ reacts with the $\mathrm{Ca}$ and $\mathrm{H}$ of hydrated cement paste at the mixing operation and forms Calcium silicate hydrate (C-S-H) gel which gives the extra binding property of that mixture. But when the \% of the SCBA is increased then the amounts of $\mathrm{Si}$ are also increased which create the imbalance proportion of $\mathrm{Si}$ with compare to $\mathrm{Ca}$ and $\mathrm{H}$. So, C-S-H is not formed such type of case and the compressive strength is reduced.

\section{Conclusion}

From the above research work, it is concluded that the percentage up to 0 to 5 of SCBA with the replacement of cement gives the best strength of concrete. But when at the time of increased above the 5\% of SCBA with the replacement of cement then the compressive strength of concrete is decreased. And the relation between the percentage increase of SCBA and workability is good. In future, further researches should be needed to know how the compressive strength is increased with the increase of more than 5\% SCBA with the replacement of cement in concrete. The costeffective admixture can be used in such type of research work.

\section{REFERENCES}

[1] S. M. I. Hossain, M. A. Zaman, M. A. Rabbani and M. S. Hossain (2006) Problems and Prospect of Sugar Industry in Bangladesh, Progress. Agric. 17, 1, pp. 283293.

[2] R. Srinivasan, K. Sathiya and M. Palanisamy (2010) Experimental Investigation in Developing Low Cost Concrete from Paper Industry Waste, Buletinul Institutului Politechnic Din IAŞI Publicat de Universitatea Tehnică "Gheorghe Asachi" din Iaşi Tomul LVI (LX), Fasc. 1, 2010 Secţia CONSTRUCŢII. ĂRHITECTURĂ.

[3] H. S. Otuoze, Y. D. Amartey, B. H. Sada, H. A. Ahmed, M. I. Sanni and M. A. Suleiman (2012) Characterization of Sugar Cane Bagasse Ash and Ordinary Portland Cement Blends in Concrete, Procs 4th West Africa Built Environment Research (WABER) Conference, pp. 24-26.

[4] U.R. Kawade, V.R. Rathi, Vaishali and D. Girge (2013) Effect of use of Bagasse Ash on Strength of Concrete, International Journal of Innovative Research in Science, Engineering and Technology, 2, 7, pp. $2997-$ 3000.

[5] Pandey A, Soccol CR, Nigam P and Soccol VT (2000) Biotechnological potential of agro-industrial residues. I: sugarcane bagasse, Bioresource Technology, 74, 1, pp. 69-80.

[6] M. Vijaya Sekhar Reddy, K. Ashalatha, M. Madhuri, P. Sumalatha (2015) Utilization of Sugarcane Bagasse Ash (SCBA) In Concrete by Partial Replacement of Cement, IOSR Journal of Mechanical and Civil Engineering, 12, 6, Ver. VI, pp. 12-16.

[7] Irfan Ahmad Najar, Devinder Sharma, Er. Munish Kumar (2017) A Review Paper on The Experimental Investigation on the Use of Bagasse Ash in the Construction of Low Volume Traffic Roads, International Research Journal of Engineering and Technology, 4, 9, pp. 1535-1538.

[8] IS: 12269-1987, Bureau of Indian standards, 
New Delhi, India, 53grade Ordinary Portland Cement-specification.

[9] Is: 4032-1985, Indian standard method of chemical analysis of hydraulic cements (First Revision).

[10] P.V. Rambabu, G. Aditya, G.V. Ramarao (2015) Effect of Acidic Environment (HCL) on Concrete with Sugarcane Bagasse Ash as Pozzolona, Int. Journal of Engineering Research and Applications, 5, 11, pp. 59-64. 